\title{
USE AND COST OF MEDICATION IN LOW RISK PREGNANT WOMEN
}

\author{
Sayuri Tanaka Maeda ${ }^{1}$ \\ Sílvia Regina Secoli ${ }^{2}$
}

Maeda ST, Secoli SR. Use and cost of medication in low risk pregnant women. Rev Latino-am Enfermagem 2008 março-abril; 16(2):266-71.

The objective of the present study is to assess the use of medication by pregnant women; classify them regarding therapy group and its risk category; and identify the cost of these drugs. The sample is formed by 47 pregnant women, in the 20 to 29 year-old age group, from July 2001 to June 2003, in the city of São Paulo. A specific instrument was used for data collection in family charts and others from the Sistema de Informação da Atenção Básica (Primary Care System Information). Average of medications used by pregnant woman was 3.63. Iron sulfate was the most commonly used, followed by antibiotics (78.7\%). Regarding risk category, $34.1 \%$ of medications belonged to category $B$ and $16.5 \%$ to category $C$. In the calculation of total costs of care, expenses with medication accounted for $11.13 \%$. We have seen the need for assessing further the criteria for use, especially of medications of category C. The higher costs were related to antimicrobials for the treatment of infections.

DESCRIPTORS: health care costs; pregnant women; drug cost

\section{USO Y COSTO DE MEDICAMENTOS PARA MUJERES EMBARAZADAS DE BAJO RIESGO}

El estudio tuvo como objetivos: identificar la utilización de medicamentos por gestantes; clasificarlos en cuanto al grupo terapéutico, categoría de riesgo e identificar los costos de esos fármacos. La muestra se constituyó de 47 gestantes, en el grupo etáreo de 20 a 29 años de edad, en el período de julio de 2001 a junio de 2003, en el municipio de Sao Paulo. Se utilizó un instrumento para la recolección de datos en historias clínicas de familias y otros del Sistema de Información de la Atención Básica. El promedio de medicamentos consumidos fue de 3,63 por gestante. El sulfato ferroso fue el más utilizado, seguido de 78,7\% antimicrobianos. En cuanto a la categoría de riesgo, 34,1\% pertenecían a la categoría B, 16,5\% a la categoría C. En el análisis de los costos totales de atención, el gasto de medicamentos representó el 11,13\%. Se vislumbró la necesidad de profundizar en el análisis de los criterios para el uso, especialmente a los de la categoría C. Los costos más elevados estuvieron relacionados a los antimicrobianos para el tratamiento de infecciones.

DESCRIPTORES: costos de la atención en salud; mujeres embarazadas; costos en drogas

\section{UTILIZAÇÃO E CUSTO DE MEDICAMENTOS EM GESTANTES DE BAIXO-RISCO}

O estudo teve como objetivos: verificar a utilização de medicamentos por gestantes; classificá-los quanto ao grupo terapêutico e sua categoria de risco; identificar os custos desses fármacos. A amostra constituiuse de 47 gestantes, na faixa etária de 20 a 29 anos, no período de julho de 2001 a junho de 2003, no município de São Paulo. Utilizou-se instrumento específico para coleta de dados em prontuários de famílias e outros do Sistema de Informação da Atenção Básica. A média de medicamentos consumidos foi de 3,63 por gestante. 0 sulfato ferroso foi o mais utilizado seguido de antibióticos (78,7\%). Quanto à categoria de risco, 34,1\% dos medicamentos pertenciam à categoria B e 16,5\% à categoria C. Na apuração de custos totais de atendimento, o gasto com medicamentos representou 11,13\%. Vislumbrou-se a necessidade de aprofundamento da análise dos critérios para uso, especialmente dos medicamentos da categoria C. Os custos mais elevados estiveram relacionados aos antimicrobianos para o tratamento de infecções.

DESCRITORES: custos de cuidados de saúde; gestantes; custos de medicamentos

${ }^{1}$ RN, PhD. Economist. Faculty, e-mail:sayuri@usp.br; ${ }^{2}$ RN, PhD, Faculty. University of Sao Paulo, School of Nursing, Brazil 


\section{INTRODUCTION}

In Brazil, after Sanitation reform, all health professions had increased responsibility and consequently more opportunities to use their knowledge, including in Nursing. This phenomenon was associated with changes in paradigms of the health/ disease concept, and the approval of Leis Orgânicas da Saúde (Organic Health Law \# 8.080/90, and \# 8.142/ 90 , with their principles and guidelines that drove the technical and management decentralization for the innovation of services to citizens.

There were also significant changes regarding the adoption of specific policies for the female population, developing from the Programa Materno Infantil (Maternal Child Program) to the Programa de Atenção Integral a Saúde da Mulher (Brazilian Program of Integral Assistance to Women's Health (PAISM), and this marked the development, at the same time, of the Brazilian National Health System (SUS). As a model, the first emphasized the biological view, which is the basis of medical formation that is still predominant. The phenomenon of "medicalization" comes from this paradigm ${ }^{(1-3)}$.

PAISM aims at an integral approach of women's need in contemporary world, where they are inserted in the job market, and are using their civil and political rights that were once only for males. These events led to new interpretations, especially of pregnancy which started to include social dimensions of these women, making and their families with them as the focus.

Pregnancy is a change that marks lives of women. It is a set of phenomena that involve women from conception to the birth of a new human being, including the change of their role in society. It produces an unstable biological balance with hormone changes that occur during the process, leading to behavior, physiological and biochemical changes. This unique condition that controls the environment of the fetus is physiologically controlled by mothers, and it requires special care concerning the exposure of women to medications. Therefore, in other clinical specialties therapeutic risks are not as big as those from pregnancy, since many of the effects of medications taken by mothers may lead to significant, irreversible, morphologic alterations that can occur in different stages of fetal development ${ }^{(2)}$.

In Brazil, studies show that use of medication during pregnancy is significant, the percentage of women using at least one agent during antenatal ranges from 83.8 to 97.6 . Additionally, $33.5 \%$ of these women use over the counter drugs ${ }^{(3-5)}$.

In the Programa de Saúde da Família (Family Health Program) (PSF), the use of medication by pregnant women is an important issue since the standard of attention of physicians and nurses is ruled by protocols that guide professional actions, presenting therapeutic indications when necessary, with standard drugs in antenatal care $^{(6)}$.

The period in pregnancy when drug is used is an important factor, and can be related to three stages, the egg from fertilization to implantation; the embryo from the second to the eight week after fertilization, and the fetal from the eighth complete week until the end of pregnancy ${ }^{(2)}$.

The embryo stage corresponds to the classic teratogenic period, because it encompasses organogenesis. Before this, drug exposure determines definitive damage leading either to death or reabsorption, or to no damage at all, however, adverse effects may occur in the fetal stage, such as, for example, with tetracycline. Other factors may influence placental transfer of drugs, such as level of absorption, maternal metabolism, protein binding, electrical charge, molecular weight, and lipid solubility of the substance ${ }^{(7)}$.

During gestational period, the access of women to medication is favored by the Programa de Assistência Farmacêutica (Pharmaceutical Assistance Program) of SUS. The objective of this program is to improve integrating economical resources, to increase financing capacities of services and obtain greater efficiency in the care of pregnant women ${ }^{(8)}$.

\section{OBJECTIVE}

To assess drug use during pregnancy; classify it according to therapy group and risk and identify costs of the therapy agents.

\section{METHODOLOGY}

Observational, descriptive study on the use and cost of medication prescribed to pregnant women. The present study is part from the results of a major project, assessing the cost of antenatal care in one unit after PSF introduction. 
The main project was assessed and approved by the Ethical Research Committee connected with the Municipal Health Secretariat of the PMSP. We have also asked for authorization of the board of the Zerbini Foundation, partner of State Health Secretariat of São Paulo in the management of this Health Unit (UBS).

The sample was made of 47 pregnant women performing antenatal control, from July 2001 to June 2003, in a UBS, located in the East side of the city of São Paulo. Eligibility criteria of this sample included pregnant women, considered low-risk from 20 to 29 years old, considered lower risk for pregnancy ${ }^{(2)}$.

For data collection, a specific instrument was designed and tested. This instrument had the identification of women's family and follow-up of care during antenatal. Medications prescribed were extracted at each medical or nursing appointment, therefore enabling to learn about the clinical history of the population studied.

Data collection was performed by researchers, who used family clinical history, record book of community agents, and the Sistema de Informação de Atenção Básica (Primary Care System Information) (SIAB) as information source.

Some social data showed conditions of life of pregnant women. We have seen that $38.3 \% \quad(n=18)$ of women were in age group from 20 to 22 years old, $29.8 \%(n=14)$ from 23 to 25 years old, and $31.9 \%$ $(n=15)$ from 26 to 29 years old. Family profile showed that $65 \%$ of pregnant women lived with 1 to 6 members and $25 \%$ had other people living with them in addition to their family members. These data indicate a likely reflex of inter-regional migration, which would partly explain the presence of big families with other relatives. However, around $10 \%$ of the charts did not present this information.

In outcome processing, medications were highlighted as a category of direct cost, and were integrated to one of the spreadsheets of the total costs of antenatal service. This spreadsheet was part of the capture of medication prescription for each of the pregnant women cared for in the period investigated.

To classify medications, we have used the Alfa System which presents as a main axis, the therapeutic use of each agent, with later division in organic and chemical system ${ }^{(7)}$.

Prices of medication were obtained through the on line Bolsa Eletrônica de Compras (BEC) of the Government of the State of São Paulo. For some items specific of odontology, invoices from the researched Unit have been verified.
We have used US dollar as a reference for the value of medications so as to make conversion easier to other countries (average value of dollar in 2003: US\$ 2.29).

\section{RESULTS AND DISCUSSION}

Currently, basic care uses the policy of pharmaceutical assistance ${ }^{(8)}$ that incorporates the principle of integral assistance and access to medication, with quality on the coverage. It is an important link in the continuity of care for SUS clients - most of them have money restrictions.

Table 1 - Distribution of the 47 pregnant women, according to medication used during pregnancy. Family Health Unit, Sapopemba. Southeast side of the city of São Paulo, 2003

\begin{tabular}{lcc}
\hline \multicolumn{1}{c}{ Medication } & \multicolumn{2}{c}{ Pregnant women } \\
& N & $\%$ \\
\hline Iron sulfate & 47 & 100.0 \\
Scopolamine + dipyrone & 22 & 46.8 \\
Polyvitamins & 14 & 29.8 \\
Metronidazole & 14 & 29.8 \\
Cephalexin & 11 & 23.4 \\
Folic acid & 10 & 21.3 \\
Diphenhydramine & 10 & 21.3 \\
Paracetamol & 9 & 19.1 \\
Ampicillin & 7 & 14.9 \\
Miconazole & 3 & 6.4 \\
Saline Nasal Solution & 2 & 4.2 \\
Methyldopa & 2 & 4.2 \\
Phenobarbital & 2 & 4.2 \\
Nistatine & 1 & 2.1 \\
Metoclopramide & 1 & 2.1 \\
Dipyrone & 1 & 2.1 \\
Luftal (Dimeticone) & 1 & 2.1 \\
Maracujina (anti-anxiety medication) & 1 & 2.1 \\
\hline
\end{tabular}

Average of medication used by pregnant women was 3.63 , and $25.5 \%$ of them were prescribed 9 agents. This result corroborates findings from other studies that pointed out an average of 4.2 drugs per pregnant woman $^{(3-5)}$.

Iron sulphate has been prescribed to all pregnant women $(100 \%)$, Polyvitamins and folic acid to $51.1 \%$ (Table 1 ). The subprogram of antenatal care recommends the use of iron supplement, and the Nursing Protocol of the $\mathrm{SMS}^{(6)}$ establishes that nurses recommend anti-anemia medication to pregnant women when clinically justified. Thus, its use is justified for the whole sample. Although studies show the efficiency of iron supplement, anemia prevalence 
due to iron deficiency was not reduced, especially in developing countries ${ }^{(9)}$. WHO stated that $58 \%$ of the pregnant women in these countries are anemic, and the consequences are preterm labor, children with low weight, greater morbidity and risk of death during labor and postpartum period ${ }^{(10)}$.

Polyvitamins (29.8\%) and folic acid (21.3\%) were prescribed to a group lower than $30 \%$, although they are also predicted on the protocol ${ }^{(6)}$. They are both essential to pregnant women, especially for those with low income such as those from our sample.

During pregnancy there is an increase in the need for nutrients, and folic acid, in addition to decreasing the occurrence of megaloblastic anemia, decreases the risk of neural-tube malformation ${ }^{(11-12)}$. A Brazilian study showed that despite the importance of Polyvitamins and of folic acid, these agents have been used by $34 \%$ and $10 \%$ of pregnant women respectively ${ }^{(13)}$.

Antispasmodic medication and pain killers (scopolamine, dipyrone and paracetamol) used by $68.1 \%(n=32)$ of the sample, have many times been prescribed with the same purpose, that is, to ease the pelvic and back pain, that are very frequent in pregnant women.

Medications of topic use such as metronidazole and nistatine were used by 15 pregnant women $(31.9 \%)$ for the treatment of vaginal infections. This kind of infection is frequent during pregnancy however, in the group studied; they may be associated with conditions of life in addition to the biological spectrum.

Regarding therapeutic classification, medications have been organized in such a way that $\mathrm{N}$ indicated the total amount of times it was prescribed and the respective percentage.

Table 2 - Distribution of medications used during pregnancy period according to the therapeutic classification. Family Health Unit, Sapopemba. Southeast side of the city of São Paulo, 2003

\begin{tabular}{|c|c|c|}
\hline \multirow{2}{*}{ Therapeutic classification } & \multicolumn{2}{|c|}{ Medication } \\
\hline & $\mathrm{N}$ & $\%$ \\
\hline Antianemic drugs & 82 & 48.2 \\
\hline Antispasmodic & 24 & 14.1 \\
\hline Antibiotics & 19 & 11.2 \\
\hline Fungicide & 18 & 10.6 \\
\hline Analgesic & 12 & 7.1 \\
\hline Antiemetics & 11 & 6.4 \\
\hline Antihipertensive & 02 & 1.2 \\
\hline Antiepileptic & 02 & 1.2 \\
\hline Total & 170 & 100.0 \\
\hline
\end{tabular}

We can see from Table 2 that the therapeutic class of antiemetics was not commonly indicated $(6.4 \%)$, since symptoms such as nausea and vomits are common in the first trimester. The group of antibiotics was prescribed to treat urinary infections in 19 pregnant women (38.3\%). Seven of them presented one episode of infection, four (8.5\%) had repeated infections, and receive antibiotics twice. In this group of 18,4 required dental treatment and used antibiotics to treat dental infections.

Urinary infections are considered one of the main clinical problems during pregnancy, and Escherichia coli is the pathogen most commonly involved. To treat this kind of infection, antimicrobials are necessary with easy administration, low cost and no side effects, offering safety for mothers and fetuses ${ }^{(14)}$. These characteristics are part of ampicillin and cephalexin, which were prescribed to pregnant women presenting this clinical condition. Ampicillin was prescribed in the first trimester, from the 3rd to the 38th week, and only one pregnant woman used cephalexin in the $12^{\text {th }}$ week.

Table 3 - Distribution of medications used during pregnancy, according to risk category. Family Health unit, Sapopemba. Southeast side of the city of São Paulo, 2003

\begin{tabular}{|c|c|c|c|}
\hline \multirow{2}{*}{$\begin{array}{c}\text { Risk } \\
\text { category }\end{array}$} & \multicolumn{2}{|c|}{ Medications } & \multirow{2}{*}{ Generic name } \\
\hline & $\mathbf{N}$ & $\%$ & \\
\hline A & 82 & 48.2 & Iron sulfate, folic acid, Polyvitamins \\
\hline B & 58 & 34.1 & $\begin{array}{l}\text { Ampicillin, cephalexin, metronidazole, } \\
\text { paracetamol, diphenhydramine, } \\
\text { nistatine, miconazole, Metoclopramide. }\end{array}$ \\
\hline $\mathrm{C}$ & 28 & 16.5 & Methyldopa, dipyrone, scopolamine \\
\hline $\mathrm{D}$ & 2 & 1.2 & Phenobarbital \\
\hline Total & 170 & 100.0 & \\
\hline
\end{tabular}

Table 3 shows the predominance of medications from risk category A (48.2\%) and B (34.1\%). However, dipyrone, scopolamine and methyldopa, risk category $\mathrm{C}$ were prescribed and in animal studies, teratogenic effects have been observed in fetuses but there are no controlled studies in women. Methyldopa and phenobarbital were recommended for pregnant women with clinical problems, however, their use was monitored. Through clinical history, it was seen that indications occurred due to pictures diagnosed in phases previous to pregnancy.

The indication for using any medication is a vital decision, since the essence of treatment was based on maternal relief and preserving fetal health. However, surveillance of the effects of these agents in the reproduction cycle of females is essential. 


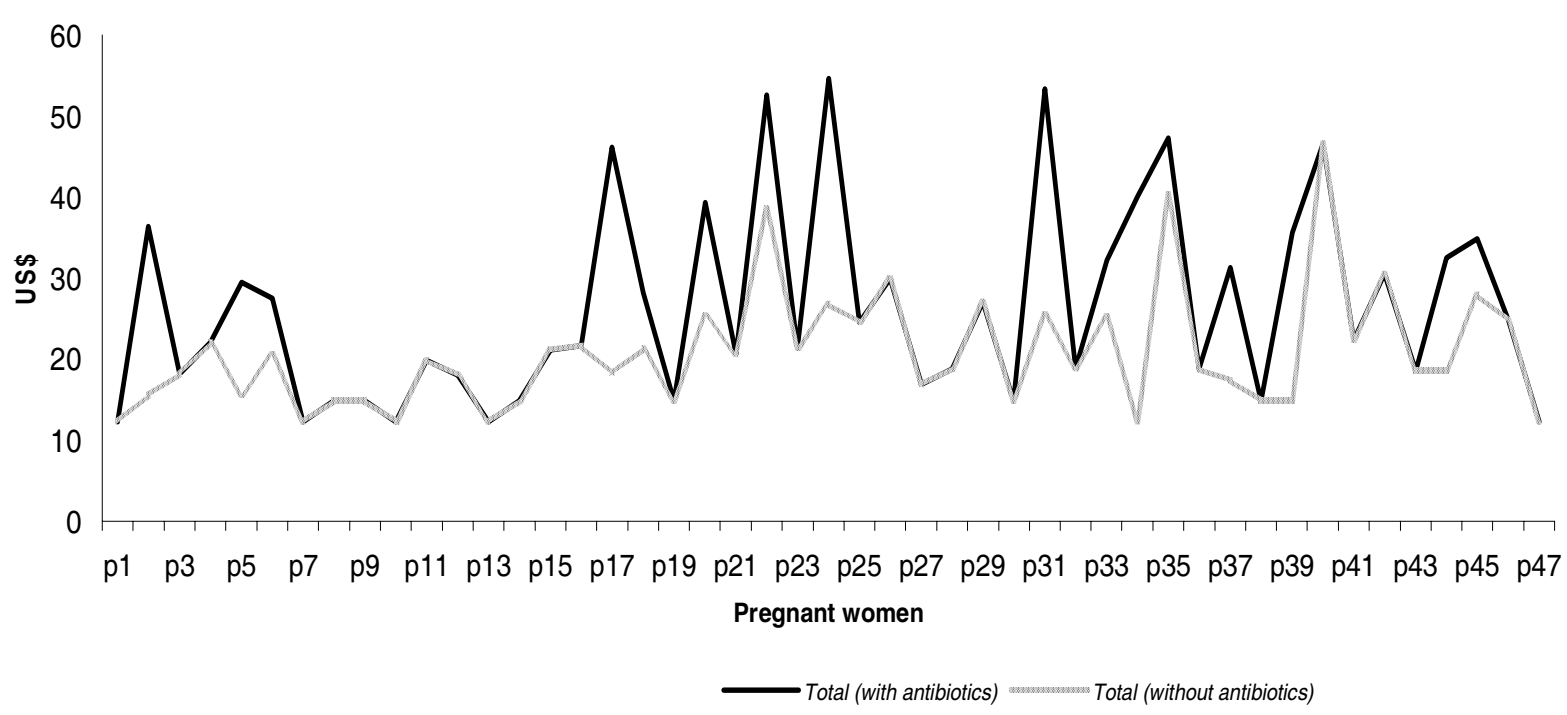

Figure 1 - Representation of the cost of medication per pregnant woman. Family Health Unit, Sapopemba. Southeast side of the city of São Paulo, 2003

Mean cost of medication per pregnant woman was US\$26.22 and median US\$22.08. The group of pregnant women presenting prescriptions limited to antianemic drugs and vitamins resulted in US\$ 12.20 and for those requiring interventions the value was US\$ 54.65. Amplitude of this interval occurred because of the 6 pregnant women presenting repeated infections. In a more detailed analysis, we have seen that without antibiotics, cost variation of medication in the antenatal period ranged from US\$12.20 and US\$29.96 (Figure 1).

In pregnant women in regular conditions, cost of medication did not present expressive values. Antibiotics increased costs. Pregnant women presented different needs, and specific personnel were allocated with a division into 3 groups: 37 pregnant women with no occurrences, 8 requiring dental attention, and 2 were followed-up by the mental health team.

Unusual events were seen in these groups. Pregnant women in normal, low-risk conditions, the assumption is that women who used more medications were those undergoing dental care or being followed-up by the mental health team. Among the 37 pregnant women, that had no apparent occurrence, they presented events that resulted in taking 1 to 9 medications. Those undergoing dental care $(n=8)$ used 1 to 6 agents and pregnant receiving mental care took 2 to 5 . Among pregnant women, $12(32.4 \%)$ received therapy for urinary infection with ampicillin or cephalexin, and among those receiving dental care, 3 needed antibiotics due to dental infection, justifying the emergency of this intervention. The events led to assumptions on the conditions of life of this population, which would partly explain repeated infections, reinforcing the assumption that these situations required interventions in health education. Thus, we could reduce costs of medications if the real need for these medications were better assessed.

Experience obtained in data collection of the present investigation demonstrated that nurses of the unit studied were taking up responsibilities of clinical follow-up of low risk antenatal ${ }^{(15)}$. In the process of clinical history collection, prescribing was the main activity, since care records focused on clinical evolvement rather than the guidelines given to patients. The other activities of the group in education actions were not documented as products.

Care protocols that guide technical behavior regarding prescription of medication are not enough to assure a risk free practice, because they involve social dimensions that are beyond prescription. Pregnant women safety must be monitored through careful assessment, from social conditions and examination of physiologic state and pharmacologic history. In this sense, systematic actions should be taken to guide health education as mandatory strategies to develop recommended values in health promotion and infection prevention.

\section{FINAL CONSIDERATIONS}

Results obtained led to the conclusion that drug prescription to pregnant women is homogeneous, and the analysis of criteria for it must be further studied, especially for those women in risk category C. 
Higher costs were related with the use of antibiotics, indicated in the treatment of infections rather than vitamin supplement and others, to maintain maternal and fetal health.

Currently, the prescription of medication by nurses, in basic care, is a well known practice that comes from changes in the role of these professionals over the years, due to their technical and political importance in basic care of SUS and from rescuing their clinical competence, due to the new health concept. In parallel, the academy needs to go deep in this issue in the education of these professionals.
If the focus of pregnancy is health, and medication is used to help pregnant women, then mothers should be encouraged to take part and be subjects in this action. These actions will give greater confidence than the act of prescribing on its own, and it will also give greater identity to the set of health care with shared production by users and professionals. A perspective of production will emerge from this point of view with social values that go beyond objective values expressed by currency, such as health costs.

\section{REFERENCES}

1. Tiefer L. The medicalization of women's sexuality. Am J Nurs 2000; 100(12): 11

2. Rezende J, Aranda OL. Anamnese e exame físico. In: Rezende J. Obstetrícia. $9^{\mathrm{a}}$ ed. Rio de Janeiro. $9^{\mathrm{a}}$ ed. Guanabara Koogan; 2000. p.179-200.

3. Carmo TA, Nitrini SMOO. Prescrições de medicamentos para gestantes: um estudo farmacoepidemiológico. Cad Saúde Pública 2005; 20(4):1-22.

4. Fonseca MRCC, Fonseca E, Bergsten-Mendes G. Prevalência do uso de medicamentos na embarazo: uma abordagem farmacoepidemiológica. Rev Saúde Pública 2002; 36(2): 205-12.

5. Mengue SS, Schenkel EP, Duncan BB, Schmidt MI. Uso de medicamentos por gestantes em seis cidades brasileiras. Rev Saúde Pública 2001; 35(5): 415-20.

6. Secretaria Municipal de Saúde (SP). Atenção à Saúde da Mulher: protocolo de enfermagem. São Paulo; 2003.

7. Silva P. Farmacologia. 6a ed. Rio de Janeiro: GuanabaraKoogan; 2002.

8. Marques MB. Patentes farmacêuticas e acessibilidade aos medicamentos no Brasil. Hist Cienc Saúde- Manguinhos 2000; 7(1): 7-21.

9. Viteri FE. Iron suplementation for the control of iron deficiency in populations at risk. Nutr Rev 1997; 55(6):195209.

10. Galloway R, Dusch E, Elder L, Achadi E, Grajeda R, Hurtado $E$, et al. Women's perception of iron deficiency and anemia prevention and control in eight developing countries. Soc Sci \& Med 2002; 55(4):529-44.

11. Grahame SDG, Aronson JK. Farmacoterapia e reprodução. $3^{a}$ ed. Rio de Janeiro: Guanabara-Koogan; 2002. p. 85-92. 12. Werler MM, Hayes C, Louik C, Shapiru S, Mitchell AA. Multivitamin supplementation and risk of birth defects. Am J Epidemiol 1999; 150(7): 675-82.

13. Cantero MAR. Fatores influenciadores da aderência ao uso de medicamentos durante a gestação. Enfoque no uso de compostos de sais de ferro e vitaminas. Rev Bras Med 2003: 60(4): 214-6.
14. Carvalho NS. Infecções urinárias na mulher. Prática Hospitalar 2004 6(32): 51- 4.

15. Maeda ST, Ciosak SI. Inversión del recurso-tiempo en la monitorización de embarazadas de bajo riesco por el equipo de salud de la família. Rev Latino-am Enfermagem 2005; 13(2): 188-94. 